\title{
Vegetable Farming by Women Farmers: A Case Study in Raichur District of North Eastern Karnataka Region
}

\author{
Jagrati B. Deshmanya*, K. Suresh, Devendra Beeraladinni, \\ Kapil Patil and Vijaya B. Wali
}

College of Agriculture, University of Agricultural Sciences, Raichur, India

*Corresponding author

Ke y w o r d s
Vegetable farming,
Cauliflower,
Tomato, Cost of
cultivation, Rural
women

\section{A B S T R A C T}

The paper explores the economic viability of vegetable farming in Raichur district of Karnataka State. The primary data were collected form women vegetable growers in Raichur District using well prepared and pre tested questionnaire. About 30 vegetable growers were selected for the study using snow ball random sampling technique. The findings of study reveal that Cauliflower, Tomato, Okra, Green chilli, Cucumber Brinjal, and Drumstick were major vegetables grown in the study region. It was observed that higher cost was incurred in tomato cultivation compared to cauliflower cultivation. The net income realized by farmers in cultivation of tomato crop was Rs. $65,870.40$ per acre and the net income was Rs. 83,192 per acre in cauliflower cultivation. The Benefit cost ratio indicates that both the vegetable farming are economically feasible and also it can be observed that tomato cultivation is less viable than cauliflower farming. So the women vegetable farmers are required to be trained in use of low cost technologies for vegetable based farming to enhance their income.

\section{Introduction}

Vegetable farming is a type of crop production in which primary intention is for human consumption of the plant's edible parts such as the shoot, leaves, fruits, and roots. In recent years vegetable crop production in the world as well as in India has consistently increased. Though vegetable farming is a labour intensive, it's very popular among farmers as an income generating farming activity. The role of rural women in cultivation of vegetables is inevitable. Most of the vegetable farming practices or operations are carried out by women in rural areas right from the preparation of land to post harvest management of crops. Rural women constitute at least $43 \%$ of the agricultural 
work force and $79 \%$ of these women depend on agriculture as their primary source of livelihood (FAO, 2011). In India too they play a crucial role in agriculture and allied activities. Vegetable cultivation provides higher employment opportunities for the small and marginal farmers as well as agricultural labourers in rural areas. Low levels of mechanization in vegetable cultivation and the need for cautious handling of produce often create a precise demand for women labor (Schreinemachers et al., 2018). This paper explores the profitability of vegetable farming among rural women farmers in Raichur District of North Eastern Karnataka region.

\section{Materials and Methods}

For the study Raichur District was selected purposively. The respondents were selected randomly. A total of 30 women vegetable growers were selected for the study using snow ball random sampling technique. A pre tested schedule was prepared for collection of data and Primary data was collected from the vegetable farmers in the study area. The collected data were tabulated and analysed by employing descriptive statistics methods. For evaluating the objectives of the current investigation, the analytical techniques used are summarized as below. The procedure and method of costing of various inputs and that of outputs included in the study are detailed below.

\section{Variable costs}

The variable costs include cost on seeds, manure, fertilizers, wages of labour- human, machine and bullock labour, plant protection chemicals, irrigation etc. and interest on operational capital and repair and maintenance charges. The actual quantity of inputs used in production and amount paid to these inputs were taken as it for the following inputs. Seed/Seedling, chemical fertilizers, FYM, plant protection chemicals, hired labour- human, bullock and machine, Costs incurred by the farmers in marketing of crop produce were also included as the cost of production. These marketing costs include cost of packing, loading charges at the field, unloading charges at the market, transportation costs, market access and other incidental charges. For the own inputs which are available at farmers dispose imputed values were estimated as per the following procedure. Own Labour: The wages paid to different hired labour components viz., human, bullock, and machine, is taken as the value for the own labour input. Seeds: The prevailing market price for the price is imputed for the own seeds of the farmers. Farm yard manure: The prevailing price per tonne was used to impute the value of farmyard manure produced on the farm (Raghavendra, 2017).

\section{Fixed costs}

These include depreciation on farm implements and machinery, interest on fixed capital, and land revenue. The measurement and definitions of fixed cost components are as follows.

Depreciation value of the implement: Per acre depreciation of implements is estimated in two steps. In the first step, the depreciation value of implement used in the production is estimated by straight line method. To this annual cost, the cost of repair and maintenance is added and the sum is divided by the size of holding of the farm to get per hectare cost of implement including its annual repair and maintenance cost. The implements and equipments used in the production by the farms are wooden plough, iron plough, harrow, tractor, cultivator, disc plough and spade etc. 
Land revenue: it is land revenue actually paid by the farmers in the study area.

Rental value of land: The practice of leasingin or leasing-out does not exist in the study area. The average value for willingness to pay for either leased-in or leisure- out in the present study area is taken as the opportunity cost for the land.

Interest on working capital: This cost is calculated at the rate of 8 per cent per annum based on the rate at which commercial banks advance crop loans.

\section{Output and returns}

In most of the vegetable crops, the output included the main yield of the crop. The gross returns are worked out by multiplying the total output with the prevailing price in the market. Net return is obtained by deducting total cost from gross return/income. Returns per rupee of Investment or Benefit cost Ratio is calculated by dividing the value of Gross income by the total cost of cultivation.

\section{Results and Discussions}

The cropping pattern followed by rural women farmers in Raichur District (Table-1) reveals that the major vegetables grown in the study area were cauliflower, tomato, okra, cucumber, green chilli, brinjal and drumstick. It is noticed that majority of women farmers grow cauliflower as vegetable crop $(24.17 \%)$ followed by tomato $(16.67 \%)$, okra $(15.00 \%)$ and cucumber $(13.33 \%)$ because the study area is proximity the Raichur city as the effective demand emanates from Raichur city ensuring remunerative prices for their produce. Apart from cultivating vegetable crops the women farmers also grow other crops like cotton $(32.91 \%)$ followed by jowar $(25.94 \%)$ and redgram $(22.15 \%)$ to augment their income and to meet their daily food requirement.

Table.1 Cropping pattern followed by women vegetable farmers in Raichur district 2019-20

\begin{tabular}{|c|l|c|c|c|c|c|}
\hline Sl.No & \multicolumn{3}{|c|}{ Vegetable crops } & \multicolumn{3}{c|}{ Other crops } \\
\cline { 2 - 7 } & Crops & $\begin{array}{l}\text { Area } \\
\text { (acres) }\end{array}$ & $\begin{array}{l}\text { Per cent to } \\
\text { total }\end{array}$ & Crops & $\begin{array}{l}\text { Area } \\
\text { (acres) }\end{array}$ & $\begin{array}{l}\text { Per cent } \\
\text { to total }\end{array}$ \\
\hline $\mathbf{1}$ & Cauliflower & 14.5 & 24.17 & Cotton & 52 & 32.91 \\
\hline $\mathbf{2}$ & Tomato & 10 & 16.67 & Jowar & 41 & 25.94 \\
\hline $\mathbf{3}$ & Okra & 09 & 15.00 & Redgram & 35 & 22.15 \\
\hline $\mathbf{4}$ & Cucumber & 08 & 13.33 & Chickpea & 30 & 18.98 \\
\hline $\mathbf{5}$ & Green chilly & 7.5 & 12.50 & & & \\
\hline $\mathbf{6}$ & Drinjal & 06 & 10.00 & & & \\
\hline
\end{tabular}


Table. 2 Cost of cultivation of tomato and cauliflower in Raichur district

\begin{tabular}{|c|c|c|c|c|c|}
\hline \multirow[t]{2}{*}{ Sl. No } & \multirow[t]{2}{*}{ Particular } & \multicolumn{2}{|c|}{ Cauliflower } & \multicolumn{2}{|c|}{ Tomato } \\
\hline & & $\begin{array}{c}\text { Cost } \\
(\text { Rs/acre })\end{array}$ & $\%$ & $\begin{array}{c}\text { Cost } \\
\text { (Rs/acre) }\end{array}$ & $\%$ \\
\hline A & \multicolumn{5}{|c|}{ Labour Cost } \\
\hline 1 & Land preparation & 5000 & 25.64 & 5000 & 16.13 \\
\hline 2 & $\begin{array}{l}\text { Manure \& fertilizer } \\
\text { application }\end{array}$ & 3000 & 15.38 & 6000 & 19.35 \\
\hline 3 & Transplanting & 2000 & 10.26 & 2000 & 6.45 \\
\hline 4 & Staking & 0 & 0.00 & 5000 & 16.13 \\
\hline 5 & PPC spraying & 3000 & 15.38 & 5000 & 16.13 \\
\hline \multirow[t]{2}{*}{6} & Harvesting and packing & 6500 & 33.33 & 8000 & 25.81 \\
\hline & sub-Total & 19500 & & 31000 & \\
\hline B & \multicolumn{5}{|c|}{ Input cost } \\
\hline 1 & $\begin{array}{l}\text { Interest on working capital } \\
\text { @ } 8 \%\end{array}$ & 3606.4 & 12.36 & 2400 & 7.41 \\
\hline 2 & Seedling cost & 8080 & 27.68 & 5000 & 15.43 \\
\hline 3 & Manure cost & 3000 & 10.28 & 6000 & 18.52 \\
\hline 4 & Chemical Fertilizers & 3500 & 11.99 & 8000 & 24.69 \\
\hline 5 & Plant protection chemicals & 7000 & 23.98 & 6000 & 18.52 \\
\hline \multirow[t]{3}{*}{6} & Marketing cost & 4000 & 13.71 & 5000 & 15.43 \\
\hline & sub- Total & 29186.4 & & 32400 & \\
\hline & Total variable cost & 48686.4 & & 63400 & \\
\hline C & \multicolumn{5}{|c|}{ Fixed Cost } \\
\hline 1 & Rental value of land & 6000 & - & 6000 & - \\
\hline 2 & Depreciation & 1500 & - & 1600 & - \\
\hline 3 & Land revenue & 20 & - & 20 & - \\
\hline \multirow[t]{3}{*}{4} & Interest on fixed capital & 601.6 & - & 609.6 & - \\
\hline & Total Fixed cost & 8121.6 & - & 8229.6 & - \\
\hline & Cost of cultivation & 56808 & - & 71629.6 & - \\
\hline
\end{tabular}


Table.3 Yield and returns of tomato and cauliflower in Raichur district

\begin{tabular}{|l|c|c|}
\hline Particulars & Cauliflower & Tomato \\
\hline Average output(qtl.) & 100 & 250 \\
\hline Price (Rs/qtl.) & 1400 & 550 \\
\hline Gross income (Rs/acre) & 140000 & 137500 \\
\hline Total cost of cultivation (Rs/acre) & 56808.00 & 71629.60 \\
\hline Net income (Rs/acre) & 83192.00 & 65870.40 \\
\hline Returns per rupee of investment & 2.46 & 1.92 \\
\hline
\end{tabular}

From Table 2, it can be seen that in cauliflower cultivation women farmers incurred higher labour cost in harvesting and packing (33.33\%) followed by land preparation $(26.64 \%)$ and manure and fertilizer application $(15.38 \%)$. Whereas in the case of tomato cultivation also the higher labour cost incurred in harvesting and packing $(25.81 \%)$ followed by Manure and fertilizer application $(19.35 \%)$ and Land preparation $(16.13 \%)$. The expenditure incurred for labour was Rs. 19500 per acre in cauliflower cultivation whereas the total labour cost was Rs. 31000 per acre in tomato cultivation. The average cost of seedlings in cauliflower cultivation was Rs. 8080 per acre and it was Rs. 5000 per acre for tomato seedlings. The expenditure incurred for chemical fertilizers was higher in tomato cultivation (Rs.8000) compared to Cauliflower (Rs. 3500). The cost incurred on plant protection chemicals was Rs. 7000 in cauliflower cultivation, whereas it is Rs. 6000 per acre for tomato cultivation. The marketing cost is higher in tomato production because tomato crop will be harvested 3 to 4 times in a season and marketed at different harvesting time. The per acre total variable cost was Rs. 48686.4 and Rs. 63400 for cauliflower production and tomato production respectively. The total fixed cost for cauliflower cultivation was Rs. 8121.6 and it was Rs. 8229.6 for tomato cultivation indicating not much difference in fixed costs. The total cost cultivation was Rs.56808 and 71629.6 for cauliflower and tomato cultivation respectively indicating higher cost was incurred in tomato cultivation. The higher cost of cultivation in tomato cultivation was mainly contributed by high marketing cost and labour cost for harvesting and packaging.

The perusal of the table 3 shows the yield and returns generated by cultivation of cauliflower and tomato crops. The yield obtained by rural women farmers was 100 quintals of cauliflower and 250 quintals of tomatoes per acre respectively. The gross income realised by the women farmers were found to be Rs. 56808.00 in cauliflower cultivation whereas it was Rs. 71629.60 in tomato cultivation. The net return realised by rural farmers were Rs. 83192.00 and Rs. 65870.40 respectively for cauliflower and tomato cultivation. The return per rupee of investment (B.C ratio) was 2.46 and 1.92 for cauliflower and tomato production respectively. The $\mathrm{B}: \mathrm{C}$ ratio indicates that both the vegetable farming is economically feasible and also it can be observed that tomato cultivation is less viable than cauliflower farming. The higher difference in net returns may be variations in price of vegetables and cost incurred on various farm operations. The similar studies by Raghavendra (2017), Vanitha et al., (2018), Raghupathi and Kumar (2018), Agarwal and Banerjee (2019) show that vegetable farming is economically feasible enterprise for women farmers. 
In conclusion, vegetable farming is known to be an assured income generating agribusiness activity because of continuous demand from the consumers in urban as well as rural areas. The rural women farmers in Raichur District are practicing vegetable farming since decades. The major vegetable crops grown by the vegetable growers in the Raichur District were Cauliflower, Tomato, Okra, Green chilli, Cucumber Brinjal, and Drumstick. The net income realised by farmers in cultivation of tomato crop was Rs. 65,870.40 per acre and the net income was Rs. 83,192 per acre in cauliflower cultivation. The returns per rupee of investment in tomato were 1.92 and the returns per rupee of investment in cauliflower was 2.46. Due to price volatility and higher input and labour cost the net returns realized in tomato cultivation is less compare to cauliflower cultivation. So there is need to reduce the cost of cultivation especially cost on fertilizers and plant protection chemicals. The women vegetable farmers are required to be trained in use of low cost technologies for vegetable based farming to enhance their income.

\section{Acknowledgement}

The study formed part of project entitled "Enhancing farm income through vegetable based cropping system in Raichur district" funded by University of Agricultural Sciences, Raichur

\section{References}

Agarwal Kumar Punit and Banerjee Arindam, 2019, Economic Analysis of Tomato Cultivation in Kandi Block of WestBengal, India, Economic Affairs, 6(43): 643-647.

FAO, 2011, The Role of Women in Agriculture. ESA Working Paper No. 11-02, Rome, Italy.

Raghupathi, R and Kumar Sanjay, 2018, An economic analysis cauliflower production in Kolar district of Karnataka. Internat. Res. J. Agric. Eco. \& Stat., 9 (1): 77-81

Raghavendra, D.V. and Sreenivasa Murthy, D., 2017, Vegetable based farming systems to augment farm income and nutrition in Kolar District, Karnataka, International Journal of Advanced Biological Research, 7(2): 289-295.

Schreinemachers Pepijn, Simmons B. Emmy and Wopereis C.S. Macro., 2018, Tapping the economic and nutritional power of vegetables, Global Food Security, 16:36-45

Vanitha S.M., Chinnappa Reddy B.V and Gajanana T.M., 2018, Economic Analysis of Profitability in Tomato Production at Different Seasons and Market Prices: a Study in Kolar district of Karnataka. International Journal of Agriculture Sciences, 10(16): 69616966.

\section{How to cite this article:}

Jagrati B. Deshmanya, K. Suresh, Devendra Beeraladinni, Kapil Patil and Vijaya B. Wali. 2020. Vegetable Farming by Women Farmers: A Case Study in Raichur District of North Eastern Karnataka Region. Int.J.Curr.Microbiol.App.Sci. 9(09): 1076-1081. doi: https://doi.org/10.20546/ijcmas.2020.909.134 